\title{
Root distribution of nitrogen fertigated sweet peppers under drip irrigation'
}

\author{
Megh R. Goyal, Manuel Crespo-Ruiz and Lais E. Rivera"
}

\begin{abstract}
A drip irrigation experiment was established 17 December 1983 at Fortuna Substation, Juana Díaz, P. R., to evaluate effects of various fertigation rates $(\mathrm{T} 1=13.8, \mathrm{~T} 2=8.3$ and $\mathrm{T} 3=4.1 \mathrm{~g}$ of $\mathrm{N}$ per plant in 10 weekly applications), fertilization (T4 $=6.9 \mathrm{~g}$ of $\mathrm{N}$ per plant on day 6 and 56 ); and no fertilization on root distribution at 0-11, 11-22, 22-33 and 33-44 soil depth. Effect of silver coated plastic mulch was also evaluated. Fresh root weight and percent distribution values at four depths were not statistically different at $\mathbf{P}=\mathbf{0 . 0 5}$ among all treatments. In all fertigation treatments under mulching, the root values were significantly higher at $P=0.05$ for 00-11 cm soil depth than values for other soil depths. More than $80 \%$ of the roots were within $\mathbf{0 0 - 2 2} \mathrm{cm}$ soil depth in all plots; this depth corresponds to wetting zone under a dripper.
\end{abstract}

\section{INTRODUCTION}

Drip irrigation is a method of partial wetting of the root zone, which resembles an onion (1). The study of root activity in this zone is essential for efficient water management. Some of the factors affecting root development are soil type, nutrients and moisture availability, climate and mulching. Bar-Yosef et al. (1) observed an increased activity of uptake of nutrients near the drippers where most of the tomato roots were concentrated $(2,7)$. Keng et al. (4) found that under drip irrigation more than half of pepper roots were located within a depth of $5-15 \mathrm{~cm}$. Knavel and Morth (6) found that tomato and pepper root development was promoted under black plastic mulch. Knnoch et al. (5) observed increase in fresh weight of wheat roots with nitrogen fertilization.

The purpose of this study was to evaluate the effect of various nitrogen fertigation rates on the root distribution at different soil depths in plastic mulched and non-mulched sweet peppers (var. Cubanelle) under drip irrigation.

'Manuscript submitted to Editorial Board 17 April 1986.

This study was condueted under H 326 (S-143), Southern Reyion Research Project, "Trickle Irrigation in Humid Regions."

${ }^{2}$ Associate Agricultural Engineer, Former Graduate student (Agxonomy) and Research Assistant, Agricultural Experiment Station, University of Puerto Rico-Mayagtiez Campus, Río Piedras, P. R. 


\section{MATERIALS AND METHODS}

The experiment was conducted at the Fortuna Substation on a San Antón soil (Cumulic Haplustolls) in the semi-arid southern coast of Puerto Rico. Four-week-old pepper seedlings (Capsicum annuum L. c.v. Cubanelle) were transplanted 17 December 1983 . Double rows of plants were spaced $30 \mathrm{~cm}$ apart between and within rows with a dual chamber drip line in the middle (3) of the bed. Fertigation treatments consisting of $\mathrm{T} 1=13.8, \mathrm{~T} 2=8.3$ and $\mathrm{T} 3=4.1 \mathrm{~g}$ of nitrogen/plant were supplied in 10 applications via drip irrigation on days $6,13,17,27,34$, $42,50,56,65$ and 79 after transplanting. In the conventional method (T4), $6.9 \mathrm{~g}$ of nitrogen per plant was side-dressed on days 6 and 56. No nitrogen was applied in the control plots (T5). Nitrogen source was urea. All treatments were replicated four times in a complete randomized split plot design. Split plots were used to evaluate the effect of silver-coated plastic mulching and no mulching. Each plot consisted of 4 beds at $1.8 \mathrm{~m}$ spacing.

After final picking in April 4, 1984, the root distribution system was evaluated using the excavation and wet method (8) at a soil depth of $00-11,11-22,22-33$ and $33-44 \mathrm{~cm}$. Soil samples from each plot were taken from a $30 \times 30 \mathrm{~cm}$ area as shown in figure 1 . Pepper plants were at the centre of a side nearest the drip line. Soil particles were loosened from the roots by washing samples in running water (8) and the roots were air dried for 3 days. Weeds were removed manually. These root samples were used to calculate root density by taking the ratio of fresh weight to wet weight of soil, and percentage distribution by taking the ratio of fresh root weight in each soil depth to fresh root weight in all four soil depths.

\section{RESULTS AND DISCUSSION}

Table 1 shows the analysis of variance of the data on the basis of split-split plot randomized complete block design. $F$-tests were conducted to check whether the differences were significant.

Figure 1 reveals fresh weight, density and percent distribution of roots at four depths in drip irrigated peppers. In all the treatments (T1, $\mathrm{T} 2, \mathrm{~T} 3, \mathrm{~T} 4, \mathrm{~T} 5)$ and subtreatments ( $\mathrm{P}$ and NP), fresh root weight was not statistically different at $\mathrm{P}=0.05$. Fresh root weight at $00-11 \mathrm{~cm}$ depth was significantly higher at $\mathrm{P}=0.01$ than fresh root weight at other depths; the fresh root weight at 11-22 cm depth was significantly higher at $\mathbf{P}=0.05$ than at $22-33 \mathrm{~cm}$ depth. There was no significant difference between fresh weight at 11-22 and 22-33; 22-33 and 33-44 cm depth.

At $00-11 \mathrm{~cm}$ depth, root density in the control plots was significantly greater at $\mathbf{P}=0.05$ than in the fertilized and fertigated plots. At other depths, root density was not significantly different at $\mathrm{P}=0.05$ among all 
TABLE 1.-Analysis of variance for root distribution in nitrogen fertigated peppers under drip imigation

\begin{tabular}{|c|c|c|c|c|c|}
\hline Origin & $\begin{array}{l}\text { Sum of } \\
\text { squares }\end{array}$ & $\begin{array}{l}\text { Degree of } \\
\text { freedom }\end{array}$ & Variance & $\mathrm{F}$ & $\begin{array}{l}\text { Standard } \\
\text { error }\end{array}$ \\
\hline \multicolumn{6}{|c|}{ Fresh root weight, $m g$} \\
\hline Fertigation (A) & $2,197,526.9$ & 4 & $549,381.7$ & $1.84 \mathrm{NS}^{1}$ & 96.65 \\
\hline Mulching (B) & $30,221.1$ & 1 & . $\quad 30,221.1$ & $0.10 \mathrm{NS}$ & 61.13 \\
\hline$A \times B$ & $709,749.7$ & 4 & $177,437.4$ & 0.59 NS & 136.69 \\
\hline \multicolumn{6}{|l|}{ Sampling } \\
\hline $\operatorname{depth}(\mathrm{C})$ & $42,627,602.1$ & 3 & $14,209,200.7$ & $47.53^{*: * 2}$ & 86.45 \\
\hline $\mathrm{AXC}$ & $3,893,562.4$ & 12 & $324,463.5$ & $1.09 \mathrm{NS}$ & 193.31 \\
\hline $\mathrm{B} \times \mathrm{C}$ & $730,015.9$ & 3 & $243,338.6$ & $0.81 \mathrm{NS}$ & 122.26 \\
\hline $\mathrm{A} \times \mathrm{BXC}$ & $2,212,896.9$ & 12 & $184,408.1$ & $0.62 \mathrm{NS}$ & - \\
\hline Error & $35,872,722.6$ & 120 & $298,399.4$ & - & - \\
\hline Total & $88,274,297.7$ & 159 & - & - & - \\
\hline \multicolumn{6}{|c|}{ Percent root distribution, \% } \\
\hline Fertigation (A) & 0.0 & 4 & 0.0 & - & - \\
\hline Mulching (B) & 0.0 & 1 & 0.0 & $0.0 \mathrm{NS}$ & 0.98 \\
\hline $\mathrm{AXB}$ & 0.0 & 4 & 0.0 & $0.0 \mathrm{NS}$ & 0.62 \\
\hline \multicolumn{6}{|l|}{ Samplin } \\
\hline $\operatorname{depth}(\mathrm{C})$ & $24,117.5$ & 3 & $8,039.2$ & 0.0 NS & 1.39 \\
\hline $\mathrm{A} \times \mathrm{C}$ & 481.9 & 12 & 40.2 & 258.29 : $: *$ & 0.88 \\
\hline $\mathrm{B} \times \mathrm{C}$ & 100.1 & 3 & 33.4 & $1.29 \mathrm{NS}$ & 1.97 \\
\hline $\mathrm{A} \times \mathrm{BXC}$ & 369.2 & 12 & 30.8 & $1.07 \mathrm{NS}$ & 1.25 \\
\hline Error & $3,734.9$ & 120 & 31.1 & $0.99 \mathrm{NS}$ & - \\
\hline Total & $28,803.6$ & 159 & - & - & - \\
\hline \multicolumn{6}{|c|}{ Rool densily } \\
\hline Fertigation (A) & $77,032.8$ & 4 & $19,258.2$ & $3.46 * 3$ & 13.18 \\
\hline Mulching (B) & $2,579,2$ & 1 & $2,579.2$ & $0.46 \mathrm{NS}$ & 8.33 \\
\hline A X B & $18,763.7$ & 4 & $4,690.9$ & $0.84 \mathrm{NS}$ & 18.64 \\
\hline \multicolumn{6}{|l|}{ Samplin } \\
\hline depth (C) & $989,197.9$ & 3 & $329,732.7$ & $59.31 * *$ & 11.79 \\
\hline $\mathrm{A} \times \mathrm{C}$ & $142,528.9$ & 12 & $11,877.4$ & $2.14 *$ & 26.36 \\
\hline $\mathrm{BXC}$ & $9,437.7$ & 3 & $3,145.9$ & $0.57 \mathrm{NS}$ & 16.67 \\
\hline $\mathrm{A} \times \mathrm{B} \times \mathrm{C}$ & $32,551.8$ & 12 & $2,712.6$ & $0.49 \mathrm{NS}$ & - \\
\hline Error & $667,170.3$ & 120 & $5,559.8$ & - & - \\
\hline Total & $1,989,262.5$ & 159 & - & - & - \\
\hline
\end{tabular}

' $\mathrm{NS}=$ Nonsignificant at the 0.05 level.

2Significant at the 0.01 level.

${ }^{3}$ Significant at the 0.05 level.

fertigation treatments and mulching treatments. Root density at 00-11 $\mathrm{cm}$ depth was significantly higher at $\mathrm{P}=0.05$ than at $11-22,22-33$ and $33-44 \mathrm{~cm}$ depth; it was significantly different $(\mathrm{P}=0.05)$ at $11-22 \mathrm{~cm}$ depth than at $33-44 \mathrm{~cm}$ depth. There was no significant difference between root density at 11-22 and 22-33 $\mathrm{cm}$ depth; 22-33 and 33-44 $\mathrm{cm}$ depth; $P$ and NP plots, respectively. 

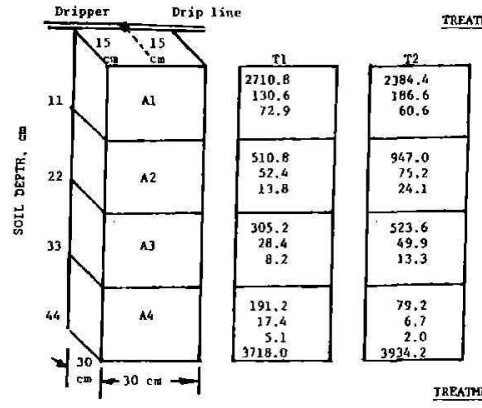

RATTENTS
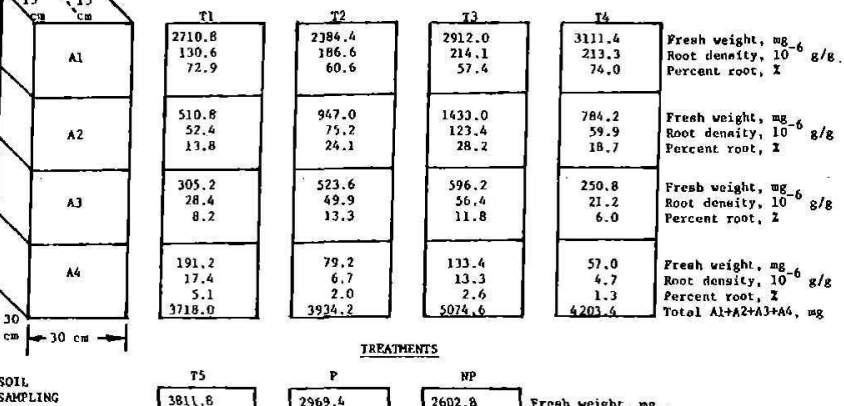

ShHPLIHG
PATTEPG
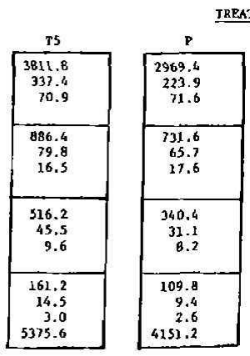

TREATMERTS

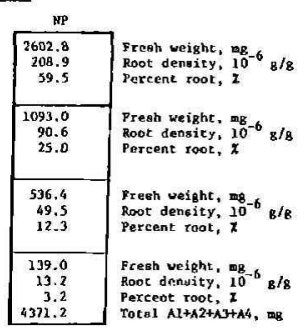

Fig. 1.-Root distribution in nitrogen fertigated sweet peppers under drip irrigation.

Percent root distribution in all fertigation and mulching treatments was not significantly different at $\mathrm{P}=0.05$. Percent root distribution at $00-11 \mathrm{~cm}$ depth was significantly higher $(\mathrm{P}=0.01)$ than at $11-22,22-33$ and $33-44 \mathrm{~cm}$ depths; there was a significant difference $(\mathrm{P}=0.05)$ between root depth at 11-22 and 22-33 cm depth, 11-22 and 33-44 cm depth. The values were not different at $\mathrm{P}=0.05$ between $22-33$ and $33-44 \mathrm{~cm}$ depth. Percent root distribution at $00-11 \mathrm{~cm}$ soil depth was $57,61,63,71,74$, 60 and $72 \%$ in T1, T2, T3, T4, T5, P and Np plots, respectively.

More than $80 \%$ of the roots were within $00-22 \mathrm{~cm}$ soil depth in all plots because the water distribution in a drip irrigation system is limited to a half onion shaped area around the dripper. This suggests a size of wetted zone of $30 \mathrm{~cm}$ diameter at soil surface and of $33 \mathrm{~cm}$ depth. Our results agree with Goyal et al. (3) who found that irrigation scheduling based upon tensiometer at $15-30 \mathrm{~cm}$ depth gave higher yield of winter peppers than to irrigation scheduling based upon tensiometers at $00-15$ and $30-45$ cm soil depth. 
RESUMEN

Distribución de las raices de pimientos abonados vía riego por goteo

Un experimento de riego por goteo se inició el 17 de diciembre de 1983 en la Subestación de Fortuna, Juana Díaz, Puerto Rico para determinar el efecto de varias concentraciones de abonamiento $(\mathrm{T} 1=13.8, T 2=8.3 \mathrm{y}$ T3 $=4.1 \mathrm{~g}$ de $\mathbf{N}$ por planta en 10 semanas de aplicación); abonamiento ( $T 4=6.9 \mathrm{~g}$ de $\mathrm{N}$ por planta en los días 6 y 56) y no abonadas en la distribución de raíces a profundidades de 0 a 11, 11 a 22, 22 a 33 y 33 a $44 \mathrm{~cm}$. en el suelo. También se estudió el efecto de la cubierta plástica plateada. El peso verde de las raíces y el porcentaje de distribución a cuatro profundidades no fueron estadísticamente significativos a un nivel de $5 \%$. En todos los tratamientos de abonamiento bajo cubierta, los valores de las raíces fueron significativamente más altos al $5 \%$ en las profundidades de suela de 0 a $11 \mathrm{~cm}$. al compararlos con los de las otros profundidades estudiadas. Más del $80 \%$ de las raíces estaban entre 0 y $22 \mathrm{~cm}$. de profundidad en todos los trafamientos; esta profundidad corresponde a la zona húmeda bajo el gotero.

\section{LITERATURE CITED}

1. Bar-Yosef, B., C. Stammers and B. Saving, 1980. Growth of trickle irrigated tomato as related to rooting volume and uptake of $\mathrm{N}$ and water. Agron. J. 72: 815-22.

2. Goldberg, D., B. Gornat and Y. Bar, 1971. The distribution of roots, water and minerals as a result of trickle irrigation. J. Am. Soc. Hort. Sci. 96: 645-48.

3. Goyal, M. R. and L. E. Rivera, 1985. Trickle irrigation scheduling of vegetables. In: Drip/Trickle Irrigation in Action Vol. II. Am. Soc. Agric. Eng., St. Joseph, MI 2: $838-43$.

4. Keng, J. C. W., T. W. Scott and M. A. Lugo-López, 1981. Fertilizer for sweet pepper under drip irrigation in an Oxisol in northwestern Puerto Rico. J. Agric, Univ. P. R. 65 (2): $123-28$.

5. Krnoch, H. G., R. E. Raming, R. L. Fox and F. E. Koehler, 1957. Root development of winter wheat as influenced by soil moisture and nitrogen fextilization Agron. J. 49: $20-25$.

6. Knavel, D. E. and H. C. Morth, 1967. Distribution of roots of four different vegetables under paper and polyethylene mulches, Am. Soc., Hort. Sci. Proc. 91: 589-97.

7. Persaud, N., S. J. Locascio and C. M. Geraldson, 1977. Influence of fertilizer rate and placement and irrigation method on plant nutrient status, soil soluble salt and root distribution of mulched tomatoes. Soil Crop Sci. Soc. Fla. Proc. 36: 121-24.

8. Schuurman, J. J. and M. A. J. Goedewaagen, 1971. Methods for the Examination of Root Systems and Roots. Center For Agricultural Publishing and Documentation, Wageningen, The Netherlands. Pages 22-43. 